\title{
Correlation of hair length and width with genetic potential for productive traits in Puerto Rican Holstein cattle ${ }^{1}$
}

\author{
Esbal Jiménez-Cabán ${ }^{2}$, Ashley Riera ${ }^{3}$ and Melvin Pagán-Morales ${ }^{4}$
}

J. Agric. Univ. P.R. 99(1):13-18 (2015)

\begin{abstract}
To demonstrate that the Holstein cow population of Puerto Rico presents differences in hair coat characteristics, hair samples were obtained from the rump, ribs and shoulder of cows visually characterized either as short (SH) or normal haired $(\mathrm{NH})$. Hair length and width were measured and correlated with the genetic potential of cows for these traits: duration of productive life, dairy conformation, pregnancy rate, milk production, milk fat, and somatic cell count (SCC). The cows phenotypically identified as $\mathrm{SH}$ had shorter but wider hairs than $\mathrm{NH}$ cows. Length of hair from the rump and ribs was inversely correlated with productive life duration and directly correlated with SCC. In addition, width of the rump and rib hair was directly correlated with milk production but inversely correlated with productive life. This variability in hair coat length and width of Holstein cattle in Puerto Rico may affect productive traits. Identification of Holstein cattle with SH phenotype should continue, thus to facilitate further genetic evaluation of this trait with the goal of improving efficiency of the local dairy industry.
\end{abstract}

Key words: slick hair, milk cattle, reproductive efficiency

\section{RESUMEN}

Correlación del largo y espesor del pelo con el potencial genético de producción en ganado Holstein puertorriqueño

Para evidenciar que en Puerto Rico existe ganado Holstein con diferencias en el largo y el espesor del pelaje, se obtuvieron muestras de pelos de la grupa, costillas y hombro de vacas identificadas visualmente como de pelo corto $(\mathrm{SH})$ o pelo normal $(\mathrm{NH})$. Se midió el largo y el espesor del pelo, y se correlacionaron estas medidas con el potencial genético de las vacas para los rasgos de duración de vida productiva, conformación lechera, tasa de preñez, producción de leche, grasa en la leche y conteo de células somáticas (SCC). Las vacas identificadas como $\mathrm{SH}$ presentaron pelo más corto pero

${ }^{1}$ Manuscript submitted to Editorial Board 18 December 2014.

${ }^{2}$ Associate Professor, Department of Animal Sciences, College of Agricultural Sciences, University of Puerto Rico, Mayagüez Campus.

${ }^{3}$ Graduate Student, Department of Animal Sciences, College of Agricultural Sciences, University of Puerto Rico, Mayagüez Campus.

${ }^{4}$ Professor, Department of Animal Sciences, College of Agricultural Sciences, University of Puerto Rico, Mayagüez Campus. 
más grueso que aquellas identificadas como NH. El largo del pelo en la grupa y costillas se correlacionó inversamente con la vida productiva, y directamente con el SCC. Además, el espesor del pelo en la grupa y costillas se correlacionó directamente con la producción de leche, pero inversamente con la vida productiva de las vacas. En el ganado Holstein de Puerto Rico existe variabilidad en cuanto al largo y espesor del pelaje, lo cual puede impactar su desempeño productivo. Se debe seguir identificando ganado Holstein con el fenotipo SH para realizar investigación genética adicional en busca de mayor eficiencia de la industria lechera local.

Palabras clave: pelo corto, ganado lechero, eficiencia reproductiva, Puerto Rico

\section{INTRODUCTION}

Evidence of a major gene influencing heat tolerance and hair length in cattle (Bos taurus taurus) was presented by Olson et al. (2003). Moreover, previous studies have shown that in Senepol cattle, animals with short hair compare favorably in terms of heat tolerance with Brahman cattle (Hammond and Olson, 1994; Hammond et al., 1996), and that Senepol F1 crossbreds with temperate breeds present heat tolerance similar to those of Brahman cattle and Bos taurus-indicus crossbreds (Hammond et al., 1996; 1998). The latter evidence suggests that such a gene is segregating within the Senepol breed and that its mode of genetic action might be complete dominance. The significance of a dominant gene of this sort, if present in dairy breeds such as Holstein, could be very important for increased productive efficiency in hot climates.

In Senepol cattle, a so-called "slick hair" gene was mapped in chromosome 20 (Mariasegaram et al., 2007). Further research in Florida showed that 3/4 Holstein: 1/4 Senepol cattle with the shorter hair (SH) phenotype better regulated their thermal balance when necessary (lower vaginal temperature and respiration rates), possibly by increased sweating rates, compared with normal haired (NH) animals (Dikmen et al., 2008). In Venezuela, Criollo Limonero cattle also exhibited differences within breed in hair coat, and although the number of sweat glands per square centimeter of skin surface area was similar in $\mathrm{SH}$ and $\mathrm{NH}$ females, the size of the sweat glands was greater in the former (Landaeta-Hernández et al., 2011). The Senepol breed, which is characterized by SH, was found to have $89 \%$ of European breed inheritance (Flori et al., 2012), and yet is well adapted to tropical regions. The latter fact underlines the importance of the SH genotype/phenotype in animals raised in warmer climates. Currently, information on SH animals is not abundant. Therefore, a study of such adaptive responses in other cattle populations, such as Puerto Rican Holsteins, deserves prompt attention. Identification of these animals permits selection for this phenotype, which could increase efficiency in milk production and other useful traits. 


\section{MATERIALS AND METHODS}

Twenty-four Holstein cows from the dairy herd of the University of Puerto Rico-Mayagüez Campus were phenotypically classified as having either short [slick (SH)] or normal hair (NH; $n=12$ per phenotype). Hair was carefully pulled out with tweezers from three different body locations: the rump, ribs and shoulder, and immediately placed in plastic bags. A blood sample $(5 \mathrm{ml})$ from each cow was obtained from the coccygeal vein.

Hair length and width were measured by using Image $J$ software and pictures obtained with a microscope ( $8 \mathrm{X}$ and $45 \mathrm{X}$, respectively). For each animal, length was measured in ten hairs per body location while width was measured at three equidistant sections per hair, four hairs per location. Blood samples were sent to Igenity ${ }^{\circledR 5}{ }^{5}$ for analysis and estimation of the genetic potential of these cows in terms of productive life, dairy form, pregnancy rate of daughter, milk production, milk fat, and somatic cell count (SCC) (dependent variables).

\section{Statistical analysis}

Differences between phenotypes, $\mathrm{SH}$ versus $\mathrm{NH}$, in hair length and width were tested using SAS GLM software. Pearson correlations were determined between both hair length and width, and the above-mentioned dependent variables.

\section{RESULTS}

There were no significant interactions between hair length or width, and body location (rump, ribs or shoulder). Hair length was shorter ( $\mathrm{P}$ $<0.0001)$ in $\mathrm{SH}(6.1 \pm 0.2 \mathrm{~mm})$ when compared to $\mathrm{NH}$ cows $(9.0 \pm 0.2$ $\mathrm{mm})$; it was also shorter $(\mathrm{P}<0.0001)$ in hair from the shoulder $(6.2 \pm$ $0.2 \mathrm{~mm}$ ) than from the rump and ribs $(8.2 \pm 0.2 \mathrm{~mm}$ in both locations). Conversely, hair width was greater $(\mathrm{P}<0.001)$ in $\mathrm{SH}(0.16 \pm 0.004 \mathrm{~mm})$ when compared to NH cows $(0.14 \pm 0.003 \mathrm{~mm})$. There was no effect of body location on hair width.

Length of rump hair was inversely correlated $(\mathrm{P}=0.08)$ with genetic potential for productive life and tended $(\mathrm{P}=0.11)$ to directly correlate with SCC (Table 1). Width of rump hair was directly correlated $(\mathrm{P}=0.09$ ) with genetic potential for milk production (Table 1). Length of hair from the ribs was directly correlated $(\mathrm{P}=0.09)$ with genetic

\footnotetext{
${ }^{5}$ Company or trade names in this publication are used only to provide specific information. Mention of a company or trade name does not constitute an endorsement by the Agricultural Experiment Station of the University of Puerto Rico, nor is this mention a statement of preference over other equipment or materials.
} 


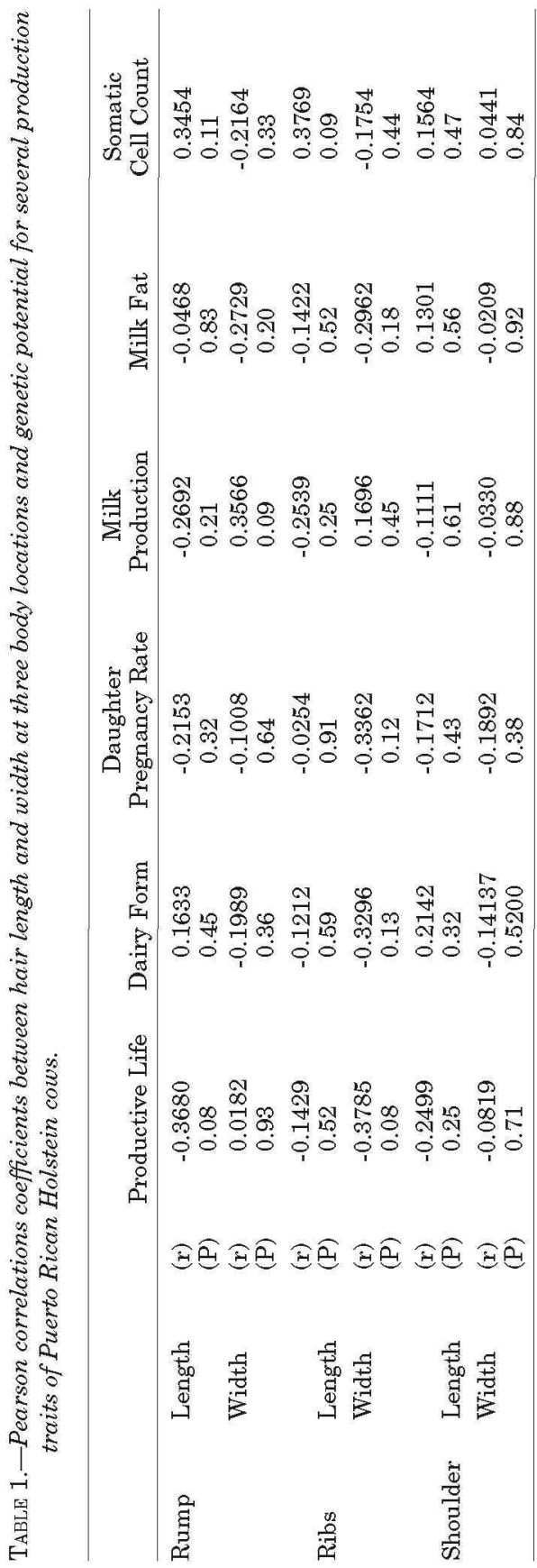


potential for SCC (Table 1), while width of hair from this location was inversely correlated $(\mathrm{P}=0.08)$ with genetic potential for duration of productive life (Table 1). The absolute value of all of these correlations fall within the range of $r=0.345$ to 0.378 . No significant correlations were found between length or width of shoulder hair and the production traits analyzed.

\section{DISCUSSION}

Of the five correlations previously cited as being worthy of mentioning, the three involving hair length suggest that the NH condition is less favorable than $\mathrm{SH}$, in view of one negative association of hair length with productive life and two positive associations with SCC. Of the two correlations involving hair width (which is greater in $\mathrm{SH}$ animals) one tends to favor SH due to a positive association with milk yield, but the other negative correlation of hair width with productive life does not favor this coat characteristic.

Current results demonstrate the existence in Puerto Rican Holstein cattle of phenotypic differences in hair length and width. In addition, González and Sánchez (Department of Animal Sciences, University of Puerto Rico-Mayagüez, personal communication) also found that Holstein cows characterized as SH showed a lower vaginal temperature (about one Celsius degree difference) than NH cows when exposed to solar radiation for two hours. The Holstein breed is of European origin and the upper limit of its comfort zone is less than 72 in the temperature-humidity index. According to this criterion, Holstein cattle in Puerto Rico suffer heat stress during all twelve months of the year. The SH condition developed in local Holstein cattle could possibly help to meliorate this year-round heat stress.

In Brazil, significant but low correlations (-0.0443) of hair diameter (width) with the number of inseminations per conception were found in Holstein cattle (Bertipaglia et al., 2005), whereas no significant correlations were found between hair length or width and milk yield (Maia et al., 2005). In terms of production traits, the current study provides evidence that cattle with shorter hair at the rump or narrower hair at the ribs might have improved genetic potential for duration of productive life while cows with shorter hair at the rump or ribs showed lower SCC in their milk. Finally, cattle with wider hair at the rump might be better milk producers. Phenotypic differences (SH condition) in hair coat of Puerto Rican Holstein cows could possibly result from genomic modifications in these animals, which may also influence other physiological responses. The SH cows in this study had both shorter and wider hair; collectively, the correlations suggest that these cows pos- 
sess better genetic potential for productive traits than NH cows. Identification of SH Holsteins, both female and male, merits prompt attention in order to further evaluate whether this phenotype/genotype might eventually have positive biological and economic effects on the local dairy industry.

\section{LITERATURE CITED}

Bertipaglia, E. C. A., R. G. Silva and A. S. C. Maia, 2005. Fertility and hair coat characteristics of Holstein cows in a tropical environment. Animal Reproduction 2(3): 187-194.

Dikmen, S., E. Alava, E. Pontes, J. M. Fear, B. Y. Dikmen, T. A. Olson and P. J. Hansen, 2008. Differences in thermoregulatory ability between slick-haired and wild-type lactating Holstein cows in response to acute heat stress. Journal of Dairy Science 91(9): 3395-3402.

Flori, L., N. I. Gonzatti, S. Thevenon, I. Chantal, J. Pinto, D. Berthier, P. M. Aso and M. Gauthier, 2012. A quasi-exclusive European ancestry in the Senepol tropical cattle breed highlights the importance of the slick locus in tropical adaptation. PloS one 7(5): 1-10.

Hammond, A. C., C. C. Jr. Chase, E. J. Bowers, T. A. Olson and R. D. Randel, 1998. Heat tolerance in Tuli-, Senepol-, and Brahman-sired F1 Angus heifers in Florida. Journal of Animal Science 76(6): 1568-1577.

Hammond, A. C., T. A. Olson, C. C. Chase, E. J. Bowers, R. D. Randel, C. N. Murphy, D. W. Vogt and A. Tewolde, 1996. Heat tolerance in two tropically adapted Bos taurus breeds, Senepol and Romosinuano, compared with Brahman, Angus, and Hereford cattle in Florida. Journal of Animal Science 74(2): 295-303.

Hammond, A. C. and T. A. Olson, 1994. Rectal temperature and grazing time in selected beef cattle breeds under tropical summer conditions in subtropical Florida. Tropical Agriculture 71: 128-134.

Landaeta-Hernández, A., S. Zambrano-Nava, J. P. Hernández-Fonseca, R. Godoy, M. Calles, J. L. Iragorri, L. Añez, M. Polanco, M. Montero-Urdaneta and T. Olson, 2011. Variability of hair coat and skin traits as related to adaptation in Criollo Limonero cattle. Tropical Animal Health and Production 43(3): 657-663.

Maia, A. S. C., R. G. da Silva, E. C. A. Bertipaglia and M. C. Muñoz, 2005. Genetic variation of the hair coat properties and the milk yield of Holstein cows managed under shade in a tropical environment. Braz. J. Vet. Res. Anim. Sci. 42: 180-187.

Mariasegaram, M., C. C. Jr. Chase, J. X. Chaparro, T. A. Olson, R. A. Brenneman and R. P. Niedz, 2007. The slick hair coat locus maps to chromosome 20 in Senepol-derived cattle. Animal Genetics 38(1): 54-59.

Olson, T. A., C. Lucena, C. C. Jr. Chase and A. C. Hammond, 2003. Evidence of a major gene influencing hair length and heat tolerance in Bos taurus cattle. Journal of Animal Science 81(1): 80-90. 